\title{
RELATIONSHIPS BETWEEN PETROGRAPHIC AND PHYSICOMECHANICAL PROPERTIES OF BASIC IGNEOUS ROCKS FROM THE PINDOS OPHIOLITIC COMPLEX, NW GREECE
}

\author{
Pomonis P. ${ }^{1}$, Rigopoulos I. ${ }^{1}$, Tsikouras B. ${ }^{1}$, and Hatzipanagiotou K. ${ }^{1}$ \\ ${ }^{I}$ University of Patras, Department of Geology, Section of Earth Materials, GR-265 00 Patras, \\ Greece,ppomonis@upatras.gr,rigopoul@upatras.gr,v.tsikouras@upatras.gr, \\ k.hatzipanagiotou@upatras.gr
}

\begin{abstract}
The relationships between petrographic and physicomechanical properties of basic igneous rocks from the Pindos ophiolitic complex, northwestern Greece, were investigated. The mineralogical composition was quantified from one polished thin section per sample with a polarizing microscope, by using the point count method. Textural description was also carried out by using both polarizing and scanning electron microscope. The same samples were also tested to determine moisture content, water absorption, specific gravity, total porosity, void ratio, uniaxial compressive strength, Los Angeles, micro-Deval, PSV and Sand Equivalent values. The relationships between these properties and the petrographic characteristics are described by simple regression analyses. The results indicate that plagioclase, chlorite, quartz and actinolite contents of the studied rock-types significantly influence their physicomechanical properties. Additionally, some textural parameters such as the mean grain size and the complexity of grain boundaries influence their mechanical strength.
\end{abstract}

Key words: aggregates, quantitative petrography, dolerites, troctolites.

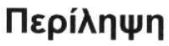

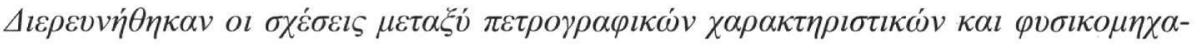

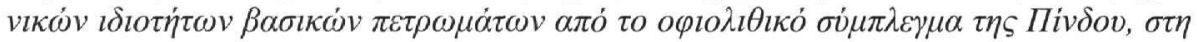

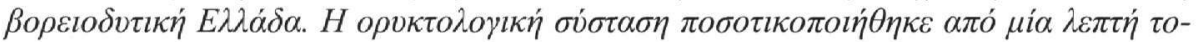

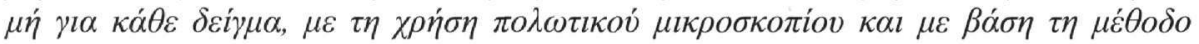

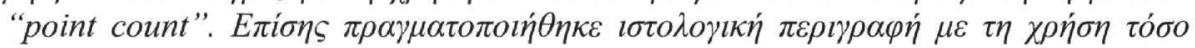

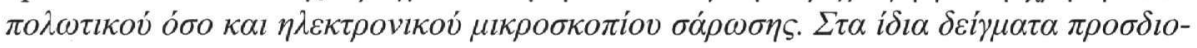

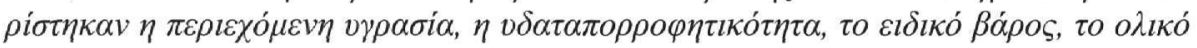

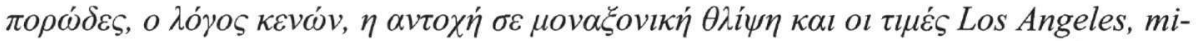

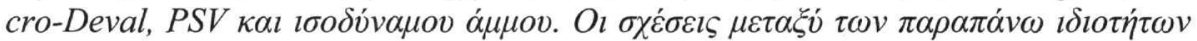

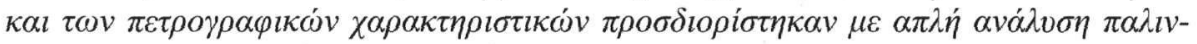

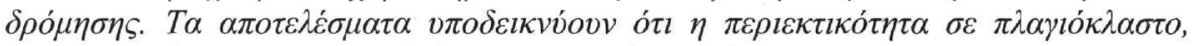

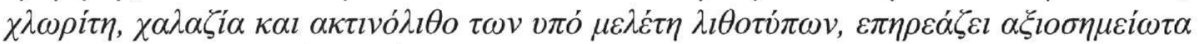

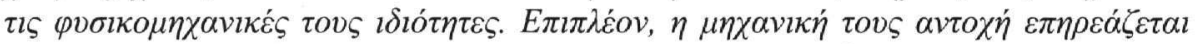

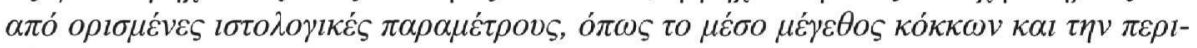

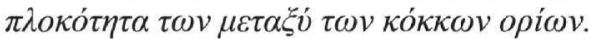

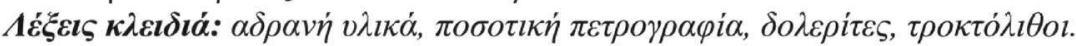




\section{Introduction}

The physicomechanical properties of rocks are the most important parameters in the design of ground workings and in the classification of rocks for engineering purposes. They are dependant on the mineralogy, texture (size, shape and arrangement of mineral grains, nature of grain to grain contacts, degree of grain interlocking), alteration and deformation of the source rock (Shakoor and Bonelli 1991, Haney and Shakoor 1994, Tuğrul and Zarif 1999, Smith and Collis 2001, Miskovsky et al. 2004, Tsikouras et al. 2005, Al-Oraimi et al. 2006, Rigopoulos et al. 2006). The correlation between the physicomechanical properties and quantitative petrography of rocks is dependant on various petrographic properties simultaneously. Thus, most studies have mainly concentrated on groups of rock or geological property: Irfan and Dearman (1978) on weathering, Brattli (1992) on basic igneous rocks, Shea and Kronenberg (1993) on schists and gneisses, Tuğrul and Zarif (1999) on granitic rocks, Åkesson et al. (2003) on foliation of granitic rocks and Räisänen (2004) on hybridisation and hornblende granites.

The aim of this study is to determine the relationships between the petrographic features and the physicomechanical properties of the samples studied, which include 4 dolerites and 2 troctolites. Physicomechanical tests and traditional petrographic description of thin sections with a polarizing microscope were performed. Point counting analyses were carried out for the quantification of the mineralogical data. In addition, scanning electron microscopy (SEM) studies were conducted, in order to determine mineral chemistry. Besides, the surface roughness and porosity of the rocks were observed by using SEM images.

\section{Geological setting}

The investigated samples comprise basic members of the Pindos ophiolite, one of the best preserved ophiolite sequences of Greece, which is located in the Subpelagonian Zone. The Pindos ophiolite complex consists of three main tectonic units: the Dramala Complex, the Aspropotamos Complex and the Loumnitsa Unit that are structurally underlain by the Avdella mélange (Jones and Robertson 1991). The Aspropotamos Complex is distinguished in eastern and western Aspropotamos Complex (Kostopoulos 1989).

The Dramala Complex consisting of harzburgite peridotite with abundant podiform dunite and some plagioclase lherzolite, is volumetrically the predominant lithology in the Pindos ophiolite complex (Jones and Robertson 1991).

The eastern Aspropotamos Complex (Kostopoulos 1989) consists of a sequence of mafic and ultramafic cumulates overlain by gabbros and minor plagiogranites with sheeted dykes, capped by a series of extrusive rocks. The western Aspropotamos Complex displays a dismembered character, including olivine-bearing isotropic gabbros with plagiogranite pods. These are stratigraphically overlain by sheeted dykes that pass upward into pillow lavas.

The Loumnitsa Unit comprises the metamorphic sole at the base of Dramala and Aspropotamos Complexes, consisting of lower amphibolite and greenschist phases metamorphic rocks of igneous and sedimentary origin. Radiometric dating on hornblende separates from the amphibolite, suggest

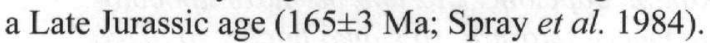

This study is concentrated on Spileo and Koridallos areas, which belong to the eastern Aspropotamos Complex and to the Avdella mélange respectively. Extensive fieldwork in these areas focused mainly on the distribution and mode of development of the mafic lithologies, as well as their relation to the adjacent formations, and resulted in detailed geological maps (Fig. 1). Sampling was performed north of the Veneticos valley (W of Spileo village) in a well preserved sheeted dyke complex (Fig. 1a) and North of the Koridallos village in troctolites (Fig. 1b). In the Veneticos valley, the sheeted dyke complex was further divided in three subunits, which are shown schematically in the geological map. Their boundaries are gradational and compose a 
sequence with fine-grained dolerite and pillow lavas, a fine- to medium-grained dolerite and a medium-grained dolerite and gabbro. The dolerite dykes show well preserved chilled margins and are locally up to $3 \mathrm{~m}$ wide. Two sets of dykes are present: an older one trending NW-SE is intruded by a younger set in a NNW-SSE direction. Intense deformation is imprinted by 1-5 m wide cataclastic zones striking NW-SE and N-S to W-E trending joints.
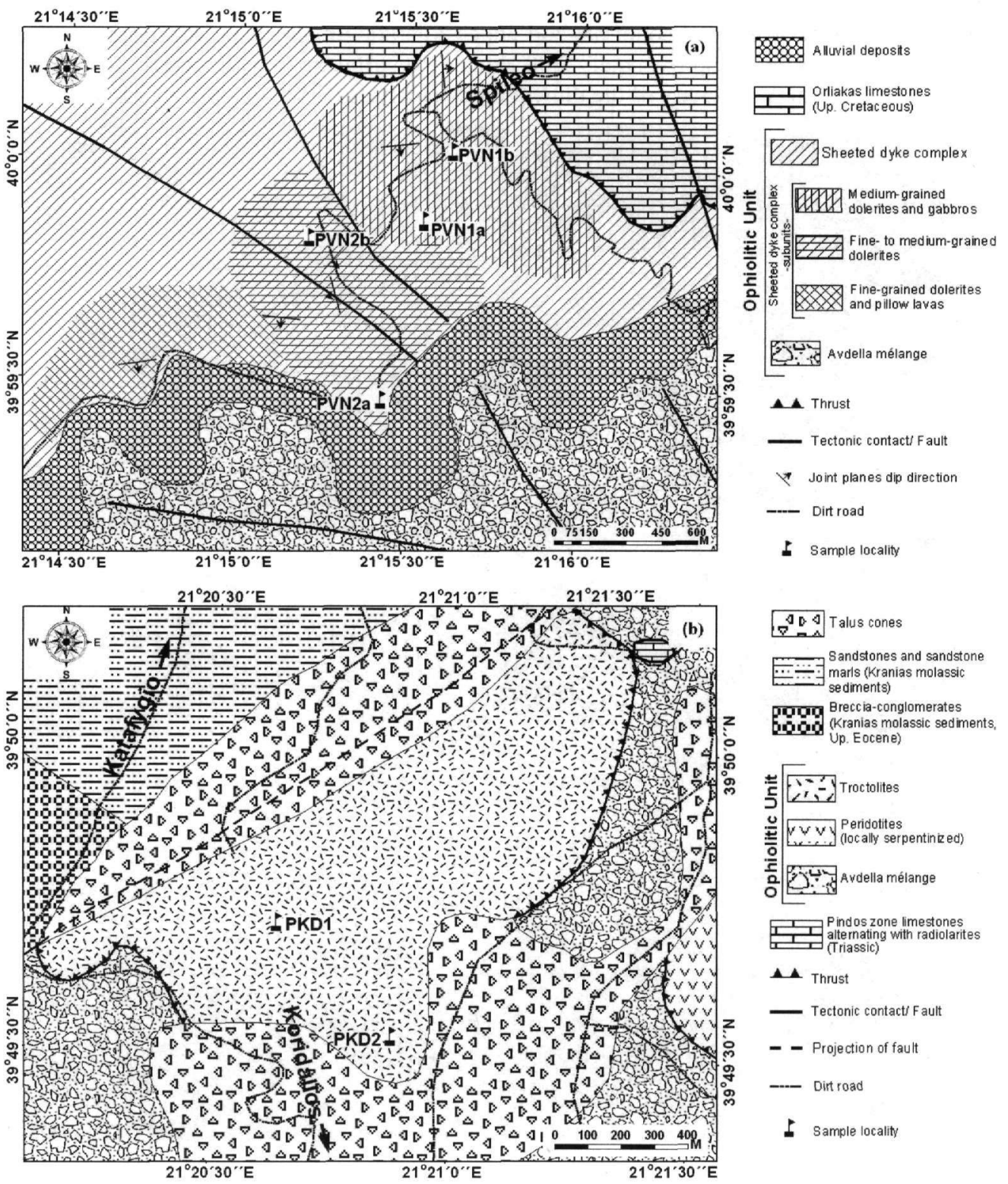

Pindos zone limestones I Triassic)

A. Thrust

- Tectonic contact/ F ault

- Projection of fault

- Dirt road

Sample locality

\section{Figure 1 - Geological - sampling map of the a) Spileo and b) Koridallos areas from the Pindos ophiolite complex}

The troctolite exposure of the Koridallos area is mapped as a discrete tectonic slice $\left(\sim 1 \mathrm{~km}^{2}\right)$ into the Avdella mélange of the Pindos ophiolite. In well preserved outcrops, troctolite shows layering. The layering is dominantly marked by distinctive alternations of plagioclase- and olivine-rich layers. This tectonic block is surrounded by a chaotic mixture of tectonically juxtaposed clasts of 
Triassic limestones, cherts and pillow lavas in a deformed mudstone-siltstone matrix which characterizes the Avdella mélange.

\section{Petrography}

The mineralogical and textural characteristics of the samples were studied by optical and scanning electron microscopy. The point count method under polarizing microscope was used to determine the modal composition. Approximately 300 equally distributed points were counted in each polished thin section. A summary of the mineralogical analysis results is given in Table 1.
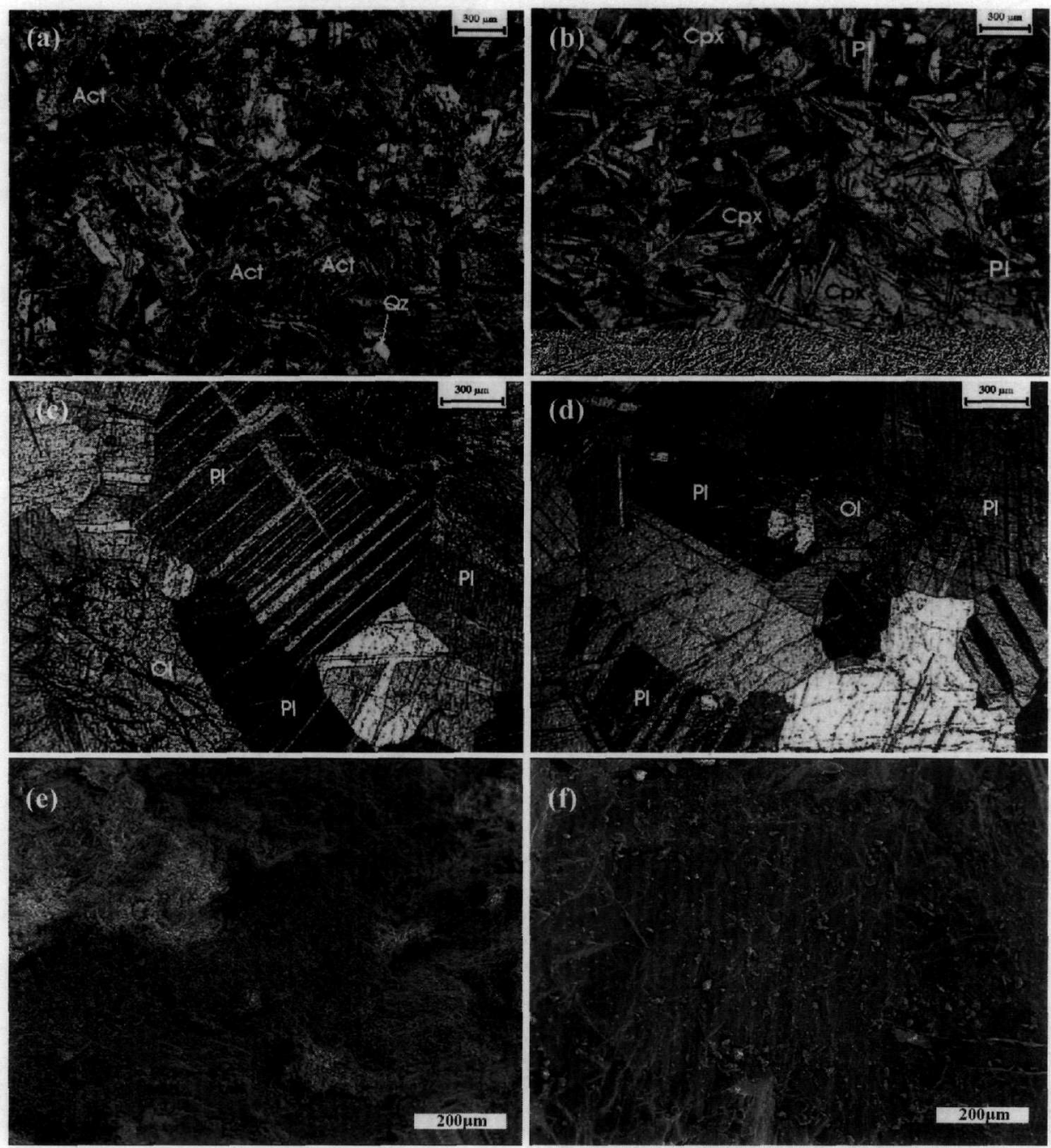

Figure 2 - Polarized photomicrographs of samples a) PVN1a, b) PVN2a, c) PKD1, d) PKD2 (Pl: plagioclase, Ol: olivine, Act: actinolite, Qz: quartz) and Secondary Electron Images showing surface roughness of e) the dolerites (sample PVN1a) and f) troctolites (sample PKD1) from the Pindos ophiolitic complex

Dolerites from the area west of Spileo are fine- to medium-grained isotropic rocks with subophitic texture (Fig. 2a, b). Laths of subhedral plagioclase and interstitial anhedral clinopyroxene comprise the subophitic groundmass. The plagioclase crystals are moderately sericitized. Hydrothermal alteration resulted in the development of chlorite, quartz, epidote, actinolite, clinozoisite and secondary titanite. Frequently these alteration products (principally epidote and 
quartz) fill veins. Small amounts of opaque minerals participate, too. Although alteration has taken place, the interlocking texture has been preserved. Micro-cracks are mainly intragranular and sparsely intergranular. Two groups of dolerites have been distinguished according to their secondary minerals contents. The first group (Fig. 2a) displays significant amounts of actinolite and quartz, while the second (Fig. 2b) is characterized by negligible amounts of actinolite and variable amounts of chlorite. In the first group, most of the clinopyroxene crystals are completely pseudomorphically replaced by actinolite.

Troctolites from the area north of Koridallos are medium- to coarse-grained rocks with cumulate texture. The only textural difference between the two troctolite samples is that PKD1 (Fig. 2c) has higher mean grain size in comparison to PKD2 (Fig. 2d). They are composed mainly of plagioclase and olivine. The cumulate texture is distinguished as alternations of plagioclase- and olivine-rich layers, however it is not always well developed. Grain boundaries are straight to slightly curved and micro-cracks are usually intragranular and rarely intergranular. Clinopyroxene and opaque minerals participate in minor concentrations. Serpentine, chlorite and quartz comprise alteration products. Olivine crystals exhibit various degrees of alteration to serpentine, while epidote and quartz fill veins through the rock.

The surface roughness and porosity of the samples studied were observed by using SEM images. Dolerites, which are fine- to medium-grained rocks, have higher surface roughness and porosity than troctolites, which are medium- to coarse-grained rocks (Figs 2e, f).

Table 1 - Mineralogical composition (in vol. \%) of the investigated rock types (Pl: plagioclase, Cpx: clinopyroxene, Act: actinolite, Ol: olivine, Chl: chlorite, Qz: quartz, Ep: epidote, Serp: serpentine, Op: opaque minerals)

\begin{tabular}{|l|l|c|c|c|c|c|c|c|c|c|}
\hline \multicolumn{1}{|c|}{ Sample } & Rock & PI & Cpx & Act & Ol & Chl & Qz & Ep & Serp & Op \\
\hline PVN1a & Dolerite & 47.7 & 13.7 & 23.3 & - & 4.3 & 7.7 & 1.3 & - & 2.0 \\
\hline PVN1b & Dolerite & 49.3 & 15.3 & 21.0 & - & 3.0 & 7.0 & 1.7 & - & 2.7 \\
\hline PVN2a & Dolerite & 50.7 & 38.0 & 0.3 & - & 7.3 & 1.0 & 0.7 & - & 2.0 \\
\hline PVN2b & Dolerite & 46.7 & 36.0 & 2.0 & - & 10.3 & 0.7 & 2.0 & - & 2.3 \\
\hline PKD1 & Troctolite & 68.7 & 1.0 & - & 12.7 & - & - & - & 17.3 & 0.3 \\
\hline PKD2 & Troctolite & 71.7 & 0.7 & - & 10.7 & - & - & - & 16.7 & 0.3 \\
\hline
\end{tabular}

\section{Mineral chemistry}

Major and minor element compositions of plagioclase, clinopyroxene, olivine, amphibole and chlorite crystals were analyzed on polished thin sections using a JEOL 6300 scanning electron microscope, equipped with EDS and WDS with a ZAF correction software information, at the Laboratory of Electron Microscopy and Microanalysis, University of Patras; operating conditions were accelerating voltage $15 \mathrm{kV}$ and beam current $3.3 \mathrm{nA}$ with $4 \mu \mathrm{m}$ diameter beam. Representative analyses are given in Table 2.

The plagioclase from the two groups of dolerites is labradorite-anorthite $\left(\mathrm{An}_{62-91}\right)$, while there is a small proportion of secondary plagioclase of albite composition. The analyzed plagioclase crystals from the troctolites are bytownite-anorthite $\left(\mathrm{An}_{86-92}\right)$. According to the Wo-En-Fs content and the I.M.A. classification system (Morimoto et al. 1988), the analyzed clinopyroxene crystals of the dolerites are augites, while the small proportion of clinopyroxene crystals of the troctolites are of diopside composition (not shown). The analyzed olivine crystals from the troctolite samples show a homogeneous composition from core to rim and are rich in forsterite component (Fo90-91). The analyzed amphiboles from the dolerites are of secondary origin and are classified as actinolite, according to the classification diagram of Leake et al. 1997 (not shown). On the classification diagram of chlorites (Hey 1954, not shown), the analyzed crystals from the dolerites plot as clinochlore. 


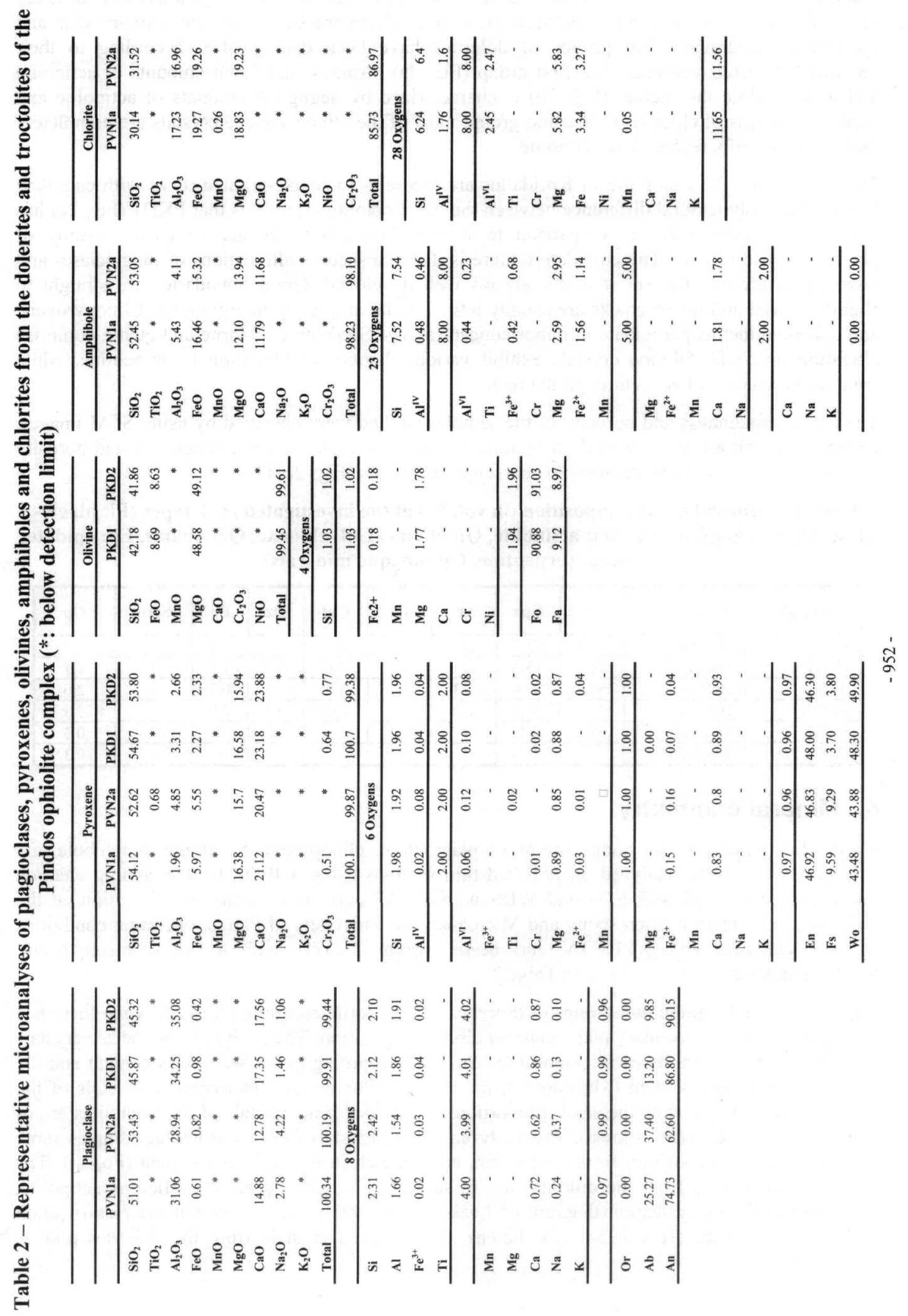


Table 3 - Whole rock chemical analyses of representative samples of dolerites and troctolites from the Pindos ophiolite (*: below detection limit)

\begin{tabular}{|c|c|c|c|}
\hline Sample & PVN1a & PVN2a & PKD1 \\
\hline Rock & Dolerite & Dolerite & Troctolite \\
\hline \multicolumn{4}{|c|}{ Major Elemets (wt.\%) } \\
\hline $\mathrm{SiO}_{2}$ & 55.42 & 49.15 & 42.30 \\
\hline $\mathbf{A l}_{2} \mathbf{O}_{3}$ & 14.68 & 17.33 & 25.51 \\
\hline $\mathrm{Fe}_{2} \mathrm{O}_{3}$ & 9.33 & 8.46 & 2.89 \\
\hline MnO & 0.13 & 0.12 & 0.03 \\
\hline MgO & 6.70 & 7.56 & 9.63 \\
\hline $\mathrm{CaO}$ & 8.30 & 10.69 & 11.88 \\
\hline $\mathrm{Na}_{2} \mathrm{O}$ & 1.84 & 2.66 & 1.03 \\
\hline $\mathrm{K}_{2} \mathrm{O}$ & 0.10 & 0.05 & 0.05 \\
\hline $\mathrm{TiO}_{2}$ & 0.20 & 0.98 & 0.01 \\
\hline $\mathbf{P}_{2} \mathbf{O}_{5}$ & 0.02 & 0.08 & $*$ \\
\hline LOI & 2.97 & 2.32 & 6.32 \\
\hline Total & 99.69 & 99.40 & 99.65 \\
\hline
\end{tabular}

\section{Whole-rock chemistry}

Whole-rock chemical analyses from 3 representative samples were performed by FUS-

ICP method (Table 3). According to their $\mathrm{SiO}_{2}$ content, the dolerites are typical basic rocks (49.15-55.42\%), however the troctolite exhibits lower $\mathrm{SiO}_{2}$ content $\left(42.30 \%\right.$ ). The higher $\mathrm{Al}_{2} \mathrm{O}_{3}$ content of the troctolite relative to the dolerites is due to the higher plagioclase content of the former (see Table 1). Los on ignition ranges between 2.32 and $6.32 \%$, with the troctolites having the higher value due to the participation of serpentine after partial alteration of olivine.

\section{Physicomechanical properties}

Knowledge of the physicomechanical properties of rock aggregates is essential in order to determine their quality. The results of the tests carried out are given in Table 4.

Physical properties investigated included moisture content (ASTM C 566), water absorption (ASTM C-128), bulk specific gravity (AASHTO T100-T85) and apparent specific gravity (ASTM C-127). Additionally, total porosity and void ratio were calculated. Three tests were performed for each property and the mean values were used. The troctolites exhibit lower moisture content, water absorption and total porosity and higher specific gravity values in comparison to the dolerites. Among the dolerite samples, PVN2a and PVN2b have higher total porosity and slightly higher water absorption and specific gravity values in comparison to PVN1a and PVN1b (Table 4).

Table 4-Mean values of physicomechanical properties of the investigated rock types

\begin{tabular}{|c|c|c|c|c|c|c|}
\hline Sample & PVN1a & PVN1b & PVN2a & PVN2b & PKD1 & PKD2 \\
\hline Moisture content (\%), $n=3$ & 0.52 & 0.44 & 0.51 & 0.56 & 0.31 & 0.22 \\
\hline Water absorption (\%), $n=3$ & 0.53 & 0.45 & 0.55 & 0.59 & 0.34 & 0.23 \\
\hline Bulk spec. gravity $\left(\mathrm{gr} / \mathrm{cm}^{3}\right), n=3$ & 2.63 & 2.68 & 2.74 & 2.77 & 2.84 & 2.78 \\
\hline Ap. spec. gravity $\left(\mathrm{gr} / \mathrm{cm}^{3}\right), n=3$ & 2.55 & 2.62 & 2.62 & 2.64 & 2.79 & 2.72 \\
\hline Total porosity (\%) & 3.04 & 2.24 & 4.38 & 4.69 & 1.76 & 2.16 \\
\hline Void ratio & 0.031 & 0.023 & 0.046 & 0.049 & 0.017 & 0.022 \\
\hline Los Angeles (\%), $n=1$ & 10.72 & 10.55 & 11.37 & 12.42 & 12.84 & 12.50 \\
\hline micro-Deval (\%), $n=1$ & 5.91 & 5.74 & 6.25 & 6.51 & 8.10 & 7.22 \\
\hline P.S.V., $n=2$ & 57 & 56 & 55 & 56 & 43 & 46 \\
\hline Sand Equivalent (\%), $n=3$ & 72 & 73 & 74 & 75 & 79 & 78 \\
\hline Un. Comp. Strength (MPa), $n=6$ & 155.59 & 162.78 & 158.34 & 149.56 & 160.07 & 187.02 \\
\hline
\end{tabular}

The mechanical properties of the investigated rocks were determined by a variety of laboratory tests. Samples were first crushed with a laboratory jaw crusher. The material was then sieved to achieve the desired fraction and tested using the Los Angeles machine (ELOT EN 1097-02/1998), which defines an aggregate's resistance to fragmentation, the micro-Deval machine (ELOT EN 1097-01), which defines an aggregate's resistance to wear and the accelerated polishing machine (ELOT EN 1097-08), which gives a measure of an aggregate's resistance to the polishing action of vehicle tyres under conditions similar to those occurring on the surface of a road. Moreover, the sand equivalent values (ELOT EN 933.08), which define the clay-like fines in aggregates passing 
ASTM Sieve No. $4(4.75 \mathrm{~mm}$ ) and the uniaxial compressive strength (ASTM D 2938-95) were determined. All of the samples studied have significantly low Los Angeles (10.55-12.84 \%) and micro-Deval $(5.74-8.10 \%)$ values, indicating their high resistance to fragmentation and wear. However, the dolerite samples have lower Los Angeles, micro-Deval and Sand Equivalent and higher PSV values in comparison to the troctolites (Table 4).

\section{Correlation analysis}

Correlation analysis was used for the estimate of the influence of petrographic factors on the physicomechanical properties of the investigated ophiolitic rocks. Selected petrographic, physical and mechanical properties were plotted against each other in order to estimate one property from another. The correlation coefficients and best fit curves were calculated by the "least squares curves fit" method. The equations for the curves plotted and correlation coefficient values are given in the diagrams.

Figure 3a, b and c shows scatter plots for the relationships between the physical properties and the petrographic characteristics of the samples studied. Good positive correlations exist between the chlorite content and both the moisture content and water absorption values (Figs 3a, b). The porosity is an important factor in rock strength in that voids reduce the integrity of the material. It was found that an increasing content of quartz causes a decrease of total porosity (Fig. 3c).

The relationships between the mechanical properties and the petrographic characteristics have also been investigated. It was found that a rising content of plagioclase causes an increase in the Los Angeles and micro-Deval test values (Figs 3d, e), that means a decrease of the resistance of the rocks to wear and fragmentation. However, it should be mentioned that the coefficient of correlation $\left(r^{2}\right)$ between the plagioclase content and the Los Angeles test values is poor $\left(r^{2}=0.47\right)$. Inverse relationships exist between the quartz content and both the Los Angeles and micro-Deval test values (Figs $3 \mathrm{f}, \mathrm{g}$ ). In Figure $3 \mathrm{~h}$ the actinolite content was plotted against PSV. It can be seen that the PSV values tend to increase with increasing actinolite content.

The various physicomechanical tests were also correlated with each other. Significant positive correlation was observed between the Los Angeles and micro-Deval test values (Fig. 4a). Besides, poor inverse relationship exists between the uniaxial compressive strength and total porosity (Fig. 4b).

\section{Discussion}

Quantitative thin section studies can give a reliable forecast of rocks strength. The study presented has mainly been focused on the influence of the mineralogical composition of the investigated basic ophiolitic rocks on their physical and mechanical properties, by using the point count method. Additionally, textural description was carried out by using both polarizing and scanning electron microscope.

Two groups of dolerites were distinguished according to the amount of their secondary minerals, however their physicomechanical properties show only slight differrences. The moisture content and water absorption tend to increase with increasing chlorite content (see Figs $3 \mathrm{a}, \mathrm{b}$ ) presumably due to absorption of water between the layers of chlorite. The negative correlation that is observed between the quartz content and the total porosity of the dolerite samples (Fig. 3c) is assigned to reduction of porosity by secondary quartz filling spaces between the other grains, analogous to what have been studied by Tuğrul and Zarif (1999).

The mechanical properties and especially the Los Angeles and micro-Deval values are influenced positively by the secondary quartz content (Figs $3 \mathrm{f}, \mathrm{g}$ ). This is due to the fact that quartz has no cleavage, so its abundance can result in higher strength. On the other hand, increasing plagioclase content influences the Los Angeles and micro-Deval values in a negative way (Figs $3 \mathrm{~d}$, e). These 

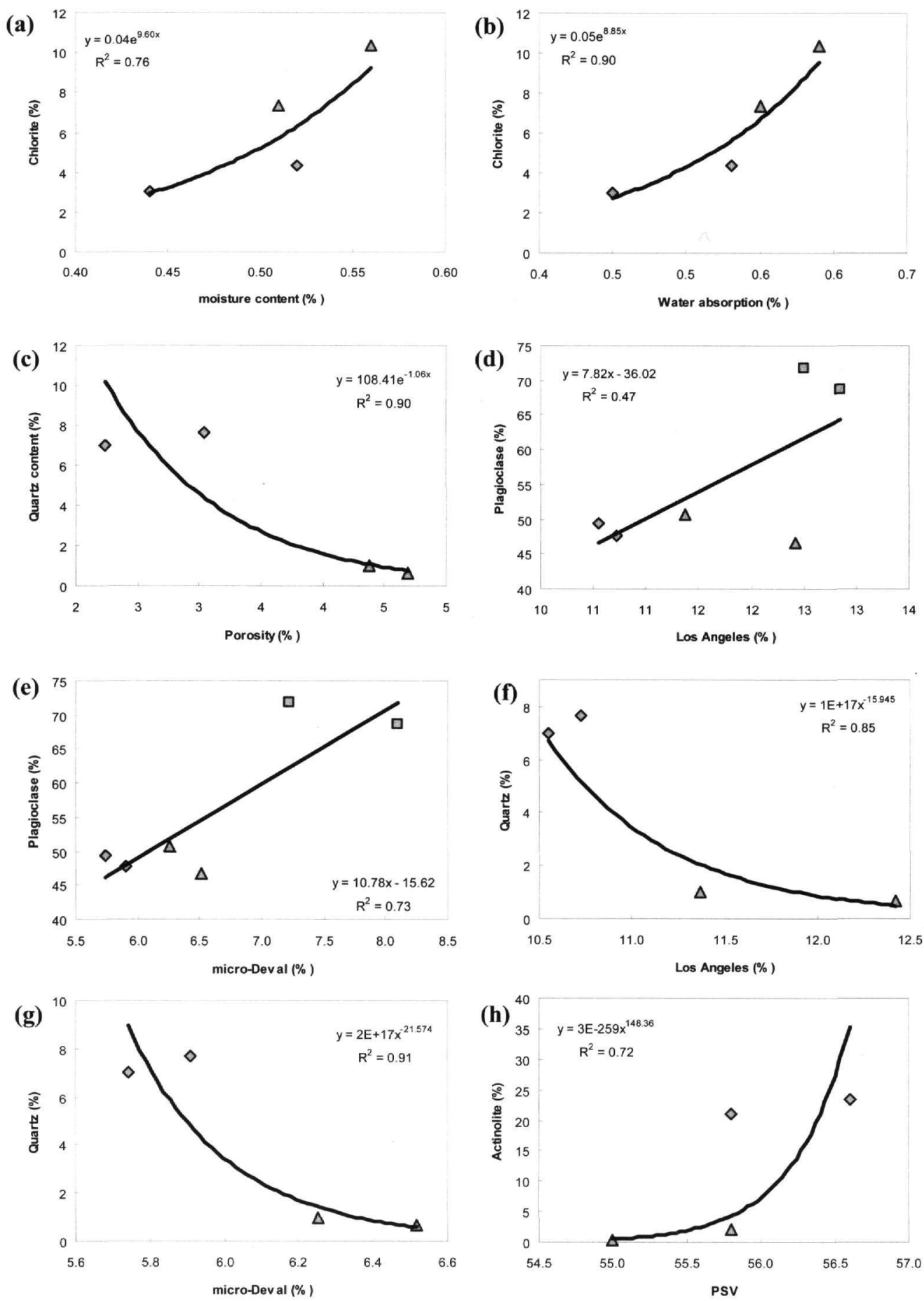

Figure 3 - Relationships between petrographic and physicomechanical properties: chlorite content plotted against (a) moisture content and (b) water absorption, (c) quartz content plotted against porosity, plagioclase content plotted against (d) Los Angeles and (e) microDeval values, quartz content plotted against (f) Los Angeles and (g) micro-Deval values, (h) actinolite content plotted against PSV values (rhombs: group A of dolerites, triangles: group B of dolerites, squares: troctolites) 

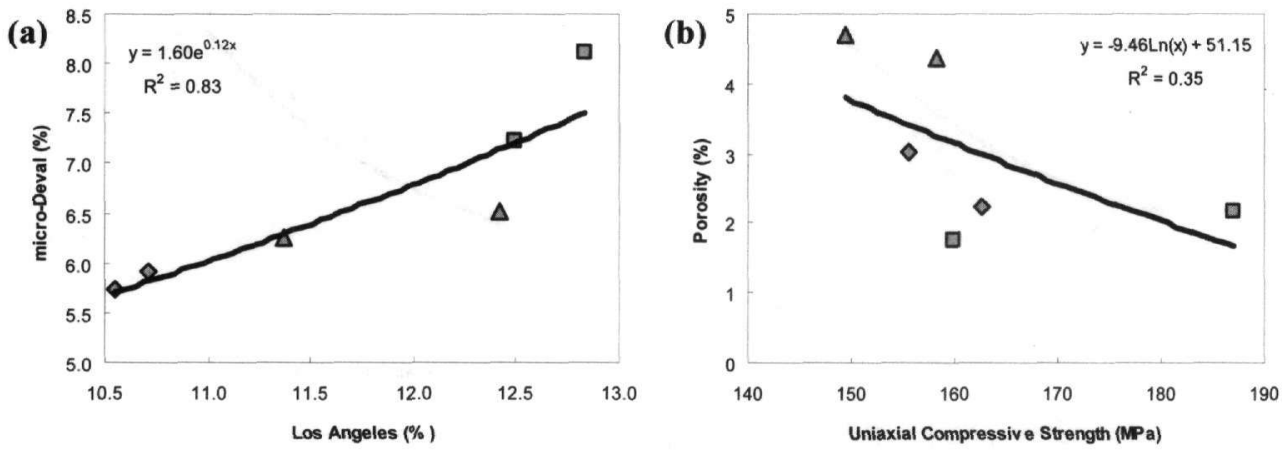

\section{Figure 4 - Relationships between: (a) the micro-Deval and the Los Angeles values, (b) the porosity and the uniaxial compressive strength. Symbols same as in Figure 3}

relationships are attributed to the perfect cleavage of plagioclase that apparently decreases the coherence of the rock. The dolerites have relatively lower plagioclase content (Table 1) and hence better mechanical properties (Table 4) compared to the troctolites. Similar relationships have also been investigated by Gunsallus and Kulhawy (1984) and Tuğrul and Zarif (1999). The replacement of clinopyroxene by actinolite in the dolerites, partly destroys their interlocking texture. This enables the rock particles to preserve their surface roughness, explaining the positive correlation between the PSV values and the actinolite content (Fig. 3h). The participation of actinolite and chlorite, together with the low mean grain size of the dolerites are the reasons for their higher PSV values compared to troctolites (Table 4).

Mean grain size is an important textural characteristic influencing the quality of aggregates. Most researchers have found that mechanical strength increases as mean grain size decreases (e.g., Olsson 1974, Haraldsson 1984, Brattli 1992, Tuğrul and Zarif 1999, Räisänen 2004). The dolerites are fine- to medium- grained rocks and have slightly better mechanical properties, in comparison to the troctolites which are medium- to coarse-grained rocks (Table 4). Among the troctolites, PKD2 sample has lower mean grain size and slightly better mechanical properties in comparison to PKD1 (Table 4). Another feature observed in thin sections is the complexity of rocks grain boundaries. The lower Los Angeles and micro-Deval values of the dolerites compared to the troctolites is also attributed to the more complex grain boundaries of the former.

The relationship between anisotropy and the mechanical behaviour of aggregates has been studied by several researchers (e.g., Schön 1996, Bohloli 2001, Åkesson et al. 2003). In this study, the mineral phases of the troctolites are not equally dispersed because of their cumulate texture. Grain boundaries between different phases result in better mechanical behavior of rocks relative to boundaries between the same phases. Based on this hypothesis, the cumulate texture of the troctolites may influence their strength, creating mechanically weak discontinuities.

\section{Conclusions}

Relationships between the petrographic characteristics and the physicomechanical properties of selected basic igneous rocks from the Pindos ophiolite complex were determined by regression analysis. The samples studied include 4 dolerites and 2 troctolites. The results of this study can be summarized as follows:

- Mineralogical composition is one of the main factors controlling the rock physicomechanical properties. Abundance of secondary minerals influences the physical properties of the dolerites. The moisture content and water absorption tend to increase with increasing chlorite content and the total porosity tends to decrease with increasing quartz content. 
- The mechanical properties of all samples studied are influenced negatively by the plagioclase content. Additionally, negative correlations were found between the secondary quartz content and both the Los Angeles and micro-Deval values of the dolerites. Significant positive correlation was also found between the actinolite content and the PSV values of the dolerites.

- The mean grain size influences the mechanical properties of the samples studied, with dolerites having higher strength than troctolites. Among the troctolites, PKD2 sample has lower mean grain size and slightly better mechanical properties in comparison to PKD1.

- The lower strength of the troctolites may also be a result of their cumulate texture and their less complex grain boundaries in comparison to the dolerites.

\section{Acknowledgements}

We thank the European Social Fund (ESF), Operational Program for Educational and Vocational Training II (EPEAEK II), and particularly the Program PYTHAGORAS, for funding the above work. We also thank J. Berger for his useful comments that have improved an earlier version of this manuscript.

\section{References}

Åkesson, U., Stigh, J., Lindqvist, J.E., and Göransson, M., 2003. The influence of foliation on the fragility of granitic rocks, image analysis and quantitative microscopy, Eng. Geol., 68, 2328.

Al-Oraimi, S.K., Taha, R., and Hassan, H.F., 2006. The effect of the mineralogy of coarse aggregate on the mechanical properties of high-strength concrete, Construction and Building Materials, 20, 499-503.

Bohloli, B., 2001. Mechanics of Rock Fragmentation, PhD thesis, Department of Geology, Chalmers University of Technology A95.

Brattli, B., 1992. The influence of geological factors on the mechanical properties of basic igneous rocks used as road surface aggregates, Eng. Geol., 33, 31-44.

Gunsallus, K.L., and Kulhawy, F.H., 1984. A comparative evaluation of rock strength measures, Int. J. Rock Mech., Min. Sci. Geomech. Abstr., 21(5), 233-248.

Haney, M.G., and Shakoor, A., 1994. The relationship between tensile and compressive strengths for selected sandstones as influenced by index properties and petrographic characteristics, Proc. $7^{\text {th }}$ Int. IAEG Cong., Lisbon, Portugal, IV, 3013-3021.

Haraldsson, H., 1984. Relation between petrography and the aggregate properties of Icelandic rocks, Bull. Int. Assoc. Eng. Geol., 30, 73-76.

Hey, M.H., 1954. A new review on the chlorites, Mineral. Mag., 224, 277-298.

Irfan, T.Y., and Dearman, W.R., 1978. The engineering petrography of weathered granite in Corn wall, England, Quart. J. Eng. Geol., 11, 233-244.

Jones, G., and Robertson, A.H.F., 1991. Tectono-stratigraphy and evolution of the Mesozoic Pindos ophiolite and related units, northwestern Greece, J. Geol. Soc. London, 148, 267-288.

Kostopoulos, D., 1989. Geochemistry, petrogenesis and tectonic setting of the Pindos ophiolite, NW Greece, Ph. D. Thesis, Univ. Newcastle, 468pp.

Leake, B.E., Wooley, A.R., Arps, C.E.S., Birch, W.D., Gilbert, M.C., Grice, J.D., Hawthorne, F.C., Kato, A., Kisch, H.J., Krivovichev, V.G., Linthout, K., Laird, J., Mandarino, J., Maresch, W.V., Nickel, E.H., Rock, N.M.S., Schumacher, J.C., Smith, D.C., Stephenson, 
N.C.N., Ungaretti, L., Whittaker, E.J.W., and Youzhi, G., 1997. Nomenclature of amphiboles; report of the Subcommittee on amphiboles of the International Mineralogical Association Commission on New Minerals and Mineral Names, Eur. J. Mineral., 9, 623-651.

Miskovsky, K., Taborda Duarte, M., Kou, S.Q., and Lindqvist, P.-A., 2004. Influence of the mineralogical composition and textural properties on the quality of coarse aggregates, Journal of Materials Engineering and Performance, 13(2), 144-150.

Morimoto, N., Fabries, J., Ferguson, A.K., Ginzburg, I.V., Ross, M., Seifert, F.A., Zussman, J., Aoki, K., and Gottardi, G., 1988. Nomenclature of pyroxenes, Am. Mineral., 73, 11231133.

Olsson, W.A., 1974. Grain size dependence of yield stress in marble, J. Geophys. Res., 79(32), 4859-4862.

Räisänen, M., 2004. Relationships between texture and mechanical properties of hybrid rocks from the Jaala - Iitti complex, southeastern Finland, Eng. Geol., 74, 197-211.

Rigopoulos, I., Pomonis, P., Tsikouras, B., and Hatzipanagiotou, K., 2006. Comparative evaluation of dolerites from the Pindos and Vourinos ophiolitic rocks for their use as aggregates, Tech. Chron. (in press)

Schön, J.H., 1996. Physical properties of rocks: fundamentals and principles of petrophysics, In K. Helbig and S. Treitel (eds), Handbook of Geophysical Seismic Exploration, vol. 18. Pergamon, Trowbridge, UK, 133-319pp.

Shakoor, A., and Bonelli, R.E., 1991. Relationship between petrographic characteristics, engineering index properties, and mechanical properties of selected sandstones, Bull. Int. Assoc. of Eng. Geol., XXVIII (1), 55-71.

Shea, W.T., and Kronenberg, A.K., 1993. Strength and anisotropy of foliated rocks with varied mica contents, Journal of Structural Geology, 15, 1097-1121.

Smith, M.R., and Collis, L., 2001. Aggregates: Sand Gravel and Crushed Rock aggregates for Construction Purposes, Geological Society, London Eng. Geol., Sp. Publ. 17.

Spray, J.G., Bébien, J., Rex, D.C., and Roddick, J.C., 1984. Age constraints on the igneous and metamorphic evolution of the Hellenic-Dinaric ophiolites, In J.E. Dixon and A.H.F. Robertson (eds), The geological evolution of the eastern Mediterranean, Geol. Soc. (London), Spec. Publ., 17, 619-627.

Tsikouras, B., Pomonis, P., Rigopoulos, I., and Hatzipanagiotou, K., 2005. Investigation for the suitability of basic ophiolitic rocks from the Mikroklissoura Grevena area as anti-skid aggregate material and railroad ballast, Proc. of the $2^{\text {nd }}$ Conference of the Committee of Economical Geology, Mineralogy and Geochemistry, 347-356.

Tuğrul, A., and Zarif, I.H., 1999. Correlation of mineralogical and textural characteristics with engineering properties of selected granitic rocks from Turkey, Eng. Geol., 51, 303-317. 